\title{
ISOLATION, IDENTIFICATION AND ANTIBIOTIC RESISTANCE OF AEROMONAS SPP. AND SALMONELLA SPP. FROM THE FRESH WATER LOACH, LEPIDOCEPHALICHTHYS GUNTEA AND WATER OF TERAI RIVER LOTCHKA, WEST BENGAL, INDIA
}

\author{
Rudra Prasad RoY ${ }^{1}$, Min BAHAdUR ${ }^{2}$ and SudiP BARAT ${ }^{1 *}$ \\ ${ }^{1}$ Aquaculture \& Limnology Research Unit, Department of Zoology, University \\ of North Bengal, District Darjeeling, Siliguri, 734013 West Bengal, India. \\ E-mail: r.rudra85@rediffmail.com \\ ${ }^{2}$ Genetics \& Molecular Biology Laboratory, Department of Zoology, University \\ of North Bengal, District Darjeeling, Siliguri, 734013 West Bengal, India. \\ E-mail:min.b@rediffmail.com \\ *Corresponding E-mail ID: sudipbarat@rediffmail.com
}

\begin{abstract}
An investigation was conducted to identify the bacterial isolates and to study the antibiotic resistance patterns of Aeromonas spp. and Salmonella spp. from the skin, gills, and gut of the fresh water loach, Lepidocephalichthys guntea (Hamilton Buchanan) and water sampled from four different sites along the River Lotchka in Darjeeling District, West Bengal, India. Isolated bacteria were identified by different biochemical procedures, and Polymerase Chain Reaction was performed using genus specific 16S rDNA primers for confirmation of identification of Aeromonas spp. and Salmonella spp. Antibiotic susceptibility test of bacterial isolates was also done by Disc Diffusion method. A total of 49 Aeromonas spp. and 24 Salmonella spp. were isolated from tested samples. Maximum resistance was exhibited for Penicillin-G, Ampicillin, and Cephalothin ( $>75 \%$ resistant Aeromonas spp. and $>60 \%$ Salmonella spp. in the four different sites of river and body parts of fish). Ciprofloxacin and Tetracycline resistance was almost nil. The results indicated that the river water and resident fish were contaminated with multi-antibiotic resistant enteric pathogenic bacteria. This study, thus, provides valuable information for making policy decisions aimed at reducing microbial contamination of fish and the indiscriminate use of antibiotics.
\end{abstract}

Key words: Antibiotic resistant Aeromonas spp. and Salmonella spp., fresh water loach, river water. 


\section{INTRODUCTION}

Lepidocephalicthys guntea (HAMILTON BuchanAN), a fresh water indigenous loach, has both ornamental (PANIGRAHI 2009) and edible value (MondAL et al. 2007) and is readily available in the local markets of Siliguri city of West Bengal, India (JHA et al. 2010). The loach is widely distributed in the region of Northern India, Pakistan, Nepal, Myanmar, Thailand, and Bangladesh (Talwar and JHINGRAN 1991), and is also very commonly found in the river Lotchka and other Terai rivers of Darjeeling district, West Bengal, India. ROY and BARAT (2011) have mentioned that domestic sewage, human excreta, and agricultural runoff are contributing to the pollution of Lotchka. Sewage discharge generates increasing loads of faecal wastes in natural waters. In many cases, the extent of pollution causes an increase in number of faecal bacteria and may contain pathogenic microorganisms like Aeromonas spp. and Salmonella spp. in high numbers beyond the assimilation capacity of the receiving water bodies (MATO 2002). These enteric bacterial pathogens are variously incriminated in cases of diarrhoea, which accounts for a substantial degree of morbidity and mortality in different age groups worldwide (Black 1993, Nath et al. 1993, Prado and O'RYAn 1994, OBi et al. 1997 and El-Sheikh and El-Assouli 2001). According to Davies (1994), Tenover and McGowan (1996), and Witte (1998), selection of resistant organisms in nature may result from natural production of antibiotics by runoff animal feed or crops and from waste products of treated animals or humans. Depending on their concentrations, the antibiotics exert a selective pressure on the microbes and may thus favour the emergence and spread of resistances among aquatic bacteria. Therefore, greater use of antibiotics will exert selective pressure, and resistant pathogens will be encountered more frequently (MacMillan 2001). The impact of these substances on the resident microflora is difficult to assess because of the complexity of the aquatic environment, whilst the resistance patterns of bacterial pathogens of fish often reflect an intensive use of antimicrobial substances (Sмітн et al. 2007). Many antibiotics have been in use for several decades in medical, veterinary, agriculture, and aquaculture practices (Chelossi et al., 2003, Costanzo et al., 2005, Alpay-Karaoglu et al. 2007), and there has also been a growing interest in the presence of different pharmaceutical substances, namely antibiotics, in the aquatic environment (Gomes-Lus 1998, Hirsch et al. 1999, Schwartz et al. 2003). This may be due to the discharge of effluents containing antibiotics into the aquatic environment from the surroundings and ultimately resulting in increased numbers of antibiotic resistant organisms. Globally, every year, 80 to 90 million more people have to be fed, and the most reliable source of protein for many is fish (World Fish Centre 2002). Bone et al. (1996) have opined that being supported by water and so with less need for a supporting skeleton, fishes have a higher ratio of muscle to bone than terrestrial animals and are thus a valuable source of protein. Among the Indian population, even though $30 \%$ to $50 \%$ are predominantly vegetarian, there is no dispute that fish is a very popular in the diet 
among the people of the States of West Bengal, Goa, and Kerala (SAKthivel 2003). Therefore, the fish Lepidocephalicthys guntea harvested from rivers has become popular in the diet of the local people. The monthly per capita consumption of fish in the rural and urban areas of West Bengal is 0.54 and $0.72 \mathrm{~kg}$, respectively. The only States with a higher per capita consumption are Kerala, Goa, Tripura, and the urban centres of Orissa (Anon 2001). The Union territories like Andaman and Nicobar Islands, Lakshwadeep, Daman and Diu, and Pondicherry also score higher consumption than West Bengal (Anon 2001). Among all these States and Union territories, people of West Bengal, Orissa, and Tripura prefer predominantly freshwater fish, whilst others prefer predominantly marine fish. Fishes are more susceptible to potentially pathogenic bacteria leading to considerable economic loss in aquaculture as a result of heavy mortalities due to physiological, environmental, and nutritional stresses. Therefore, the present investigation was aimed at identifying by biochemical and molecular tools and techniques, and studying the antibiotic resistance patterns of Aeromonas spp. and Salmonella spp. collected from both the water and the resident fish, Lepidocephalicthys guntea of the river Lotchka.

\section{MATERIALS AND METHODS}

\section{Study Area}

Four different sampling sites (S1, S2, S3, and S4) from a stretch of 18.2 kilometres lying between the latitudes $26^{\circ} 42^{\prime} 25.71^{\prime \prime} \mathrm{N}$ to $26^{\circ} 41^{\prime} 22.47^{\prime \prime} \mathrm{N}$ and longitudes $88^{\circ} 20^{\prime} 54.78^{\prime \prime} \mathrm{E}$ to $88^{\circ} 22^{\prime} 00.20^{\prime \prime}$ E were selected along the river Lotchka of Darjeeling district, West Bengal, India for the bacteriological study of water samples and selected body parts of the fresh water loach, Lepidocephalicthys guntea. Water samples, and live, healthy loaches were collected from the river at monthly intervals during the period of study from March 2009 to February 2011.

\section{Bacterial enumeration and identification}

During each sampling, 10-12 freshly caught fishes from all the sites along the river Lotchka were brought to the laboratory in sterile plastic bags containing the river water and processed within two hours of their collection. Through dissection, skin, gills, and gut samples of each fish were removed aseptically and collected separately in sterile containers. Skin, gills, and gut had been particularly selected because these organs are associated with their surrounding environment. The organs were then homogenized in a sterile glass tissue homogenizer. River water samples from each of the four sampling sites for bacteriological analysis were also collected at monthly intervals in sterile glass bottles. Serial dilutions of both homogenized organs and water samples were prepared in sterile physiological saline and plated onto Bismuth Sulphite Agar and Aeromonas Starch DNA Agar Base (HiMedia Laboratories Ltd, Mumbai, India) for colony count and recovery of the selective organisms using the Spread Plate 
technique (ОкрокWASIli and AlapiKi 1990). All of the plates were incubated at $37 \pm 1^{\circ} \mathrm{C}$ for $24-48$ hours. After incubation, the selective media plates were examined, and the growth of colonies on the plates were recorded for count of Salmonella spp. and Aeromonas spp. Growing colonies on selective media was followed by the streaking method for isolation of pure cultures. The bacterial isolates were then used for observation of cell morphology followed by the Gram Staining procedure. Biochemical tests were then performed involving IMvic tests, $\mathrm{H}_{2} \mathrm{~S}$ production, Urease, Oxidase, Citrate, Aesculine hydrolysis, Arginine utilization, and Acid and Gas production from different carbohydrates (BARROW and Feltham 1993, Holt et al. 1994 and Cheesbrough 2000).

\section{Genomic DNA extraction and PCR identification}

Genomic DNA was extracted from each bacterial isolates by lysozymes, freeze-thawing, and phenol-chloroform method (LeE et al. 1996) and DNA was stored at $-20^{\circ} \mathrm{C}$ for further use.

Genus specific 16S rDNA primers (Table 1) were used for the confirmation of identification of Aeromonas spp. and Salmonella spp. Polymerase chain reaction (PCR) was done with a thermal cycler using the amplification programme followed by Lee et al. 2002 and Аmit-Romach et al. 2004. The PCR mixtures consisted of $2.5 \mu \mathrm{l}$ of $10 \mathrm{X}$ buffer (with $\left.\mathrm{MgCl}_{2}\right), 3 \mu \mathrm{l}$ of dNTP mixtures $(2.5 \mu \mathrm{M}$ each), $1 \mu 1$ of each primer and $0.5 \mu 1$ of Taq DNA polymerase $(3 \mathrm{U} / \mu 1)(\mathrm{GENEI}$, BANGALORE), in a final volume of $25 \mu \mathrm{l}$. Finally, $50 \mathrm{ng}$ DNA template were used in each mixture. The product of these primers are approximately $953 \mathrm{bp}$ (Aeromonas ssp.) and 396 bp (Salmonella spp.).

Table 1. Genus specific 16S rDNA primers.

\begin{tabular}{lllll}
\hline Primers & Sequence (5'-3') & $\begin{array}{l}\text { Amplicon } \\
\text { Length }\end{array}$ & $\begin{array}{l}\text { Annealing } \\
\text { Temp }\end{array}$ & References \\
\hline $\begin{array}{l}\text { Ar-F } \\
\text { Ar-R }\end{array}$ & $\begin{array}{l}\text { CTACTTTTGCCGGCGAGCGG } \\
\text { TGATCCCGAAGGCACTCCC }\end{array}$ & $953 \mathrm{bp}$ & $68^{\circ} \mathrm{C}$ & $\begin{array}{l}\text { Lee } \text { et al. } \\
2002\end{array}$ \\
Sal-F & CGGGCCTCTTGCCATCAGGTG & $396 \mathrm{bp}$ & $60^{\circ} \mathrm{C}$ & $\begin{array}{l}\text { Amit-Romach } \\
\text { et al. } 2004\end{array}$ \\
Sal-R & CACATCCGACTTGACAGACCG & & & \\
\hline
\end{tabular}

\section{Antibiotic Susceptibility test}

Fresh cultures of Aeromonas spp. and Salmonella spp. isolates in nutrient broth were inoculated on a Mueller-Hinton Agar (HiMedia Laboratories Ltd, Mumbai, India) plate for determination of antibiotic resistance pattern by a Disc Diffusion method (BAUER et al. 1966) for the ten antibiotics $(\mu \mathrm{g} / \mathrm{ml})$ namely Penicillin (10), Ampicilliin (10), Streptomycin (10), Gentamycin (10), Tetracycline (30), Kanamycin (30), Ciprofloxacin (5), Moxifloxacin (5), Erythromycin (15), 
Cephalothin (30) (HiMedia Laboratories Ltd, Mumbai, India). Antibiotic discs were placed on inoculated agar plates, and after overnight incubation at $37^{\circ} \mathrm{C}$, resistance was estimated by measuring the inhibition zone as per standards given in the manufacturer's manual.

\section{RESULTS}

\section{Bacterial enumeration and identification}

Maximum counts of the Aeromonas spp. $\left(2.3 \times 10^{6} \mathrm{cfu} \mathrm{g}^{-1}\right)$ and Salmonella spp. $\left(2.2 \times 10^{4} \mathrm{cfu} \mathrm{g}^{-1}\right)$ were recorded in the gut and minimum (Aeromonas spp. $1.7 \times 10^{6} \mathrm{cfu} \mathrm{g}^{-1}$ and Salmonella spp. $\left.1.4 \times 10^{4} \mathrm{cfu} \mathrm{g}^{-1}\right)$ in the skin of the fish, whereas that in river water samples the maximum counts of Aeromonas spp. (2.6 $\left.\mathrm{x} 10^{6} \mathrm{cfu} \mathrm{ml} \mathrm{l}^{-1}\right)$ and Salmonella spp. $\left(8.8 \times 10^{4} \mathrm{cfu} \mathrm{ml}^{-1}\right)$ were recorded at S4 site (Table 2).

Table2. Mean \pm Standard Deviation values of bacterial counts $\left(\mathrm{cfu}^{-1}\right.$ ) in water samples at four sites along the river Lotchka and in different body parts of the fish, Lepidocephalicthys guntea.

\begin{tabular}{|c|cccc|ccc|}
\cline { 2 - 7 } \multicolumn{1}{c|}{} & \multicolumn{3}{c|}{ Sites along River Lotchka } & \multicolumn{3}{c|}{ Body parts of fish } \\
\hline Bacteria & S1 & S2 & S3 & S4 & Skin & Gills & Gut \\
\hline $\begin{array}{c}\text { Aeromonas } \text { spp. } \\
\left(\mathrm{x} 10^{6}\right)\end{array}$ & $2.2 \pm 1.4$ & $2.1 \pm 1.5$ & $2.3 \pm 1.6$ & $2.6 \pm 1.6$ & $1.7 \pm 1.8$ & $2.1 \pm 2.2$ & $2.3 \pm 2.4$ \\
$\begin{array}{c}\text { Salmonella } \text { spp. } \\
\left(\mathrm{x} 10^{4}\right)\end{array}$ & $0.04 \pm 0.1$ & $0.06 \pm 0.2$ & $1.3 \pm 7.7$ & $8.8 \pm 5.3$ & $1.4 \pm 0.5$ & $1.9 \pm 0.6$ & $2.2 \pm 0.8$ \\
\hline
\end{tabular}

A total of 49 Aeromonas spp. and 24 Salmonella spp. were isolated from the skin, gills, and gut of the fish and in the water samples at the four sites along the river. All of the isolates were Gram negative, motile, and rod shaped bacteria. Results of the other biochemical characterizations are shown in Table 3.

The visualization of positive amplicons (Figs. 1a and 1b) was performed by agarose gel (1.5\%) electrophoresis containing ethidium bromide. All isolates were identified as Aeromonas spp. and Salmonella spp. by 16S rDNA based technique for increasing the reliability of identification.

\section{Antibiotic resistance}

The antibiotic resistance of Aeromonas spp. and Salmonella spp. showed a full range of resistance $(0-100 \%)$ for the ten antibiotics (Table 4$)$ which are commonly used in humans and in aquaculture. Maximum resistance was exhibited for Penicillin-G, Ampicillin, and Cephalothin (>75\% resistant Aeromonas spp. and $>60 \%$ Salmonella spp. at the four different sites of the river for water samples and body parts of the fish namely skin, gills, and gut). In the case of Ciprofloxacin and Tetracycline, minimum resistance $(<9 \%$ and $<20 \%)$ was shown. 
Table3. Biochemical profile of the bacterial isolates

\begin{tabular}{lcc}
\hline Biochemical characteristics & Aeromonas spp. & Salmonella spp. \\
\hline Gram stain & $-\mathrm{ve}$ & $-\mathrm{ve}$ \\
$\mathrm{MR}$ & $-\mathrm{ve}$ & $+\mathrm{ve}$ \\
$\mathrm{VP}$ & $+\mathrm{ve}$ & $-\mathrm{ve}$ \\
Indole & $+\mathrm{ve}$ & $-\mathrm{ve}$ \\
$\mathrm{H}_{2}$ S production & $\mathrm{nd}$ & $+\mathrm{ve}$ \\
& & \\
Aesculine & $+\mathrm{ve}$ & $\mathrm{nd}$ \\
hydrolysis & & \\
Arginine & $+\mathrm{ve}$ & $\mathrm{nd}$ \\
utilization & & \\
Citrate & $\mathrm{nd}$ & $+\mathrm{ve}$ \\
utilization & & \\
Glucose & $+\mathrm{ve}$ & $+\mathrm{ve}$ \\
Lactose & $\mathrm{nd}$ & $-\mathrm{ve}$ \\
Sorbitol & $\mathrm{nd}$ & $+\mathrm{ve}$ \\
Mannitol & $\mathrm{nd}$ & $+\mathrm{ve}$ \\
Raffinose & $\mathrm{nd}$ & $+\mathrm{ve}$ \\
Sucrose & $+\mathrm{ve}$ & $-\mathrm{ve}$ \\
Salicin & $+\mathrm{ve}$ & $\mathrm{nd}$ \\
Maltose & $+\mathrm{ve}$ & $\mathrm{nd}$ \\
Arabinose & $-\mathrm{ve}$ & $+\mathrm{ve}$ \\
Inositol & $+\mathrm{ve}$ & $\mathrm{nd}$ \\
\hline & &
\end{tabular}

+ve-Positive, -ve-Negative, nd-Not done

\section{DISCUSSION}

High counts of different opportunistic bacterial genera observed in the body parts of the fish, Lepidocephalicthys guntea, is a reflection of the surrounding environment (ROY and BARAT 2011). Al-HARBI (2003) reported that aquatic microflora are associated with the physiology of fish. There is an indication that the type of bacteria found in the gastrointestinal tract of fish is related, to a certain degree, to the level of contamination of water by enteric bacteria (APUn et al. 1999). 


\begin{tabular}{|c|c|c|c|c|c|c|c|c|}
\hline \multirow{2}{*}{ 芯 } & $\approx$ & 0 & 0 & 8 & 0 & 0 & 10 & 0 \\
\hline & $\bar{\simeq}$ & 0 & 0 & "ே & 0 & 0 & 0 & 0 \\
\hline \multirow{2}{*}{ 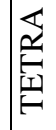 } & $\mathbb{2}$ & 0 & 0 & 0 & 0 & 0 & 0 & 0 \\
\hline & $\widetilde{\simeq}$ & 0 & 0 & 0 & 0 & 0 & 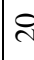 & 0 \\
\hline \multirow{2}{*}{$\begin{array}{l}\underset{x}{x} \\
\sum^{2}\end{array}$} & $\mathscr{\simeq}$ & 0 & 0 & ¿ & 0 & 0 & 10 & 0 \\
\hline & $\bar{\simeq}$ & $\simeq$ & $a$ & $\infty$ & 0 & 0 & 10 & 0 \\
\hline \multirow{2}{*}{$\begin{array}{l}0 \\
\frac{\alpha}{\theta} \\
\frac{\theta}{0}\end{array}$} & $\approx$ & 0 & 0 & f & 0 & 0 & 10 & 0 \\
\hline & $\bar{\simeq}$ & 0 & $a$ & $\infty$ & 0 & 0 & 10 & 0 \\
\hline \multirow{2}{*}{ 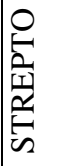 } & $\approx$ & $\stackrel{n}{a}$ & q & $\triangleright$ & 0 & 0 & 10 & 0 \\
\hline & $\widetilde{\simeq}$ & 0 & $\hat{\lambda}$ & $\underline{\bullet}$ & 0 & 0 & 10 & $₹$ \\
\hline \multirow{2}{*}{ 茫 } & $\approx$ & a & ¿ి & 8 & in & 0 & $m$ & 5 \\
\hline & $\widetilde{\simeq}$ & 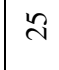 & in & $\infty$ & 0 & 0 & กิ & $\delta$ \\
\hline \multirow{2}{*}{ 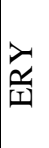 } & $\approx$ & 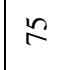 & 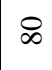 & 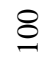 & in & in & 6 & 5 \\
\hline & $\widetilde{\simeq}$ & $\simeq$ & in & ‡ & 27 & 0 & q & 5 \\
\hline \multirow{2}{*}{ 这 } & $\approx$ & 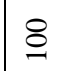 & 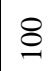 & 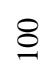 & in & in & 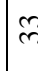 & 5 \\
\hline & $\bar{\simeq}$ & $\stackrel{n}{2}$ & t & $\alpha$ & 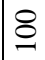 & 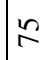 & छ & 5 \\
\hline \multirow{2}{*}{ 㞵 } & $\approx$ & $\nsubseteq$ & 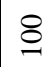 & 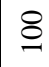 & 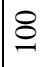 & 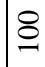 & $£$ & $\oint$ \\
\hline & $\bar{\simeq}$ & 8 & \& & 8 & 8 & 8 & $£$ & 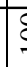 \\
\hline \multirow{2}{*}{$\sum_{i}$} & $\approx$ & $\approx$ & 8 & 8 & 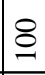 & $£$ & 6 & $\S$ \\
\hline & $\bar{q}$ & $\stackrel{2}{2}$ & $\tilde{\infty}$ & $\Phi$ & 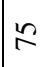 & $\approx$ & $£$ & $\delta$ \\
\hline 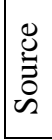 & U & $\frac{.}{\frac{\Xi}{\omega}}$ & $\bar{\nabla}$ & $\bar{J}$ & $\bar{n}$ & $\tilde{\kappa}$ & $\tilde{n}$ & $\delta$ \\
\hline
\end{tabular}



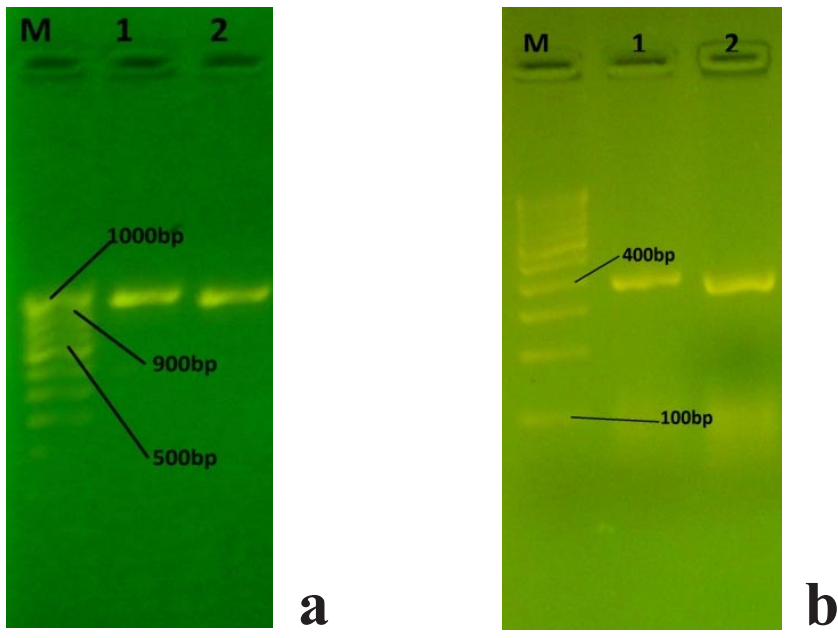

Fig. 1. a. Aeromonas spp. specific 16S rDNA PCR amplification. Lane M: 100 bp molecular weight marker, Lane 1- 2: amplicons b. Salmonella spp. specific $16 \mathrm{~S}$ rDNA PCR amplification. Lane M: 100 bp molecular weight marker, Lane 1- 2: amplicons

Motile aeromonads are naturally present in aquatic environments and therefore may be expected to occur in fish (CAhILl 1990). Massa et al. (2001) reported, Aeromonas spp. are ubiquitous inhabitants of aquatic ecosystems such as freshwater, coastal water, and sewage. These bacteria are usually natural microbiota as well as primary or secondary pathogens of fish (CAHILL 1990, JANDA and Аввотт 1998). It has been frequently considered that Salmonella spp. are opportunistic and potential pathogenic bacteria of water bodies in warm climatic zones and poses a great risk for human health (Heinitz et al. 2000). Salmonella spp. infections can be life-threatening, especially for the very young, the elderly, and for persons with impaired immune systems. It is clear that the contamination of Salmonella spp. with or without antimicrobial resistance has become a food safety problem.

Percentage of multi-antibiotic resistant patterns were higher in the gut than in the skin and gills, this could be due to bacterial load being maximum in the gut of the fish. Many researchers mentioned that the gut of many fishes contain a wide variety of bacteria (SUgita et al., 1982, SAKATA et al. 1984, CAHILL 1990). The percentage patterns of resistant isolates were similar in fish and river water. Several molecules belonging to the same chemical family are usually affected by a single mechanism of resistance (cross-resistance). Both Ampicillin and Cephalothin, for example, are inactivated by chromosomal beta lactamases produced by many Aeromonas species (WALSH et al. 1995). Most studies on 
bacterial antibiotic resistances in sewage (Al-Jebouri 1985; Fernandez et al. 1990) and freshwater (РАтнак et al. 1993) did not take into account these elements, leading to unexpected conclusions. Jones et al. (1986) found a higher incidence of resistance in the bacteria isolated from remote upland tarns than in those isolated from a polluted lake or sewage, with the highest values being observed for Pseudomonads, which are naturally multi-resistant organisms. Similarly, McKeon et al. (1995) reported that $100 \%$ of A. hydrophila strains isolated from rural groundwater supplies were resistant to at least two antibiotics, but among the tested antibiotics, A. hydrophila was found to be naturally resistant to Ampicillin and Cephalothin (WALsh et al. 1995). The resistance exhibited for Erythromycin, Kanamycin, Ciprofloxacin, and Gentamycin is a signal of the ineffectiveness of broad spectrum antibiotics of the present generation. With these observations, it appears that the source of the problem of antibiotic resistance in riverine ecosystems is due to faecally contaminated water and fish populations in them (PATHAK and Gopal 2005). Similar to our study, antibiotic resistance motile Aeromonads were also found in fresh water fishes (НАTHA et al. 2005) and in Danish rainbow trout (Schmidt et al. 2000). SAHA and PAL (2002) reported on the multiple antibiotic resistant Aeromonas hydrophila isolated from Epizootic Ulcerative Syndrome (EUS) affected fish in India.

RoY and BARAT (2011) reported that the River Lotchka received sewage and waste from surface runoff and effluents discharged from surrounding inhabitants and agriculture fields. Antibiotics are predominantly water soluble and enter the aquatic environment through sewage systems following consumption and excretion by humans and via effluent from farms, abattoirs, and landfills (Daughton and Ternes 1999). The occurrence of resistance for common antibiotics is an indication of indiscriminate use of these antibiotics leading to constraint in antimicrobial therapy for infectious diseases. Antibiotics released into the aquatic environment are of concern for the following reasons: (i) contamination of raw, treated, and recycled water used for drinking, irrigation, and recreation, (ii) potential to accelerate widespread bacterial resistance to antibiotics, and (iii) negative effect on the bacteria important for ecosystems (through death or inhibition). Between $30 \%$ and $90 \%$ of an administered dose of most antibiotics to humans and animals are excreted in the urine as the active substance (RANG et al. 1999). The loss of antibiotic susceptibility among aquatic bacteria has been observed to be affected to a considerable extent by the physico-chemical qualities of the water (РАТНAK et al. 1993). This investigation, therefore, signifies that antibiotics and resistant bacteria are entering our local waterways and have the potential to influence biotic processes. The occurrence of antibiotic-resistant pathogenic bacteria in surface waters and aquaculture environments is also a well-known phenomenon that carries a negative impact for public health and for the safety of the fish supply (GonzÁlez et al. 1999, TOROGLU et al. 2005). 
The results indicated that the fish was contaminated with multi-antibiotic resistant enteric pathogenic bacteria and evidently provides valuable information for making policy decisions aimed at reducing microbial contamination of fish and the indiscriminate use of antibiotics. Thus, there is a need for research on antibiotic susceptibility surveillance in aquatic environments from where water and fish are collected for human consumption.

\title{
Acknowledgements
}

The authors are grateful to the University Grants Commission, New Delhi, India for providing financial support in the form of a fellowship. They also wish to express their gratitude to Prof. B B Jana, Vice Chairman, International Centre for Ecological Engineering (ICEE), University of Kalyani, India, Prof. T K Misra, University of Illinois, Chicago and Prof. D C Deb, Department of Zoology, University of North Bengal, India for their critical review and suggestions for upgrading the manuscript.

\author{
IZOLACJA, IDENTYFIKACJA I OPORNOŚĆ NA ANTYBIOTYKI \\ AEROMONAS SPP. I SALMONELLA SPP. Z SE SŁODKOWODNEJ RYBY \\ PISKORZOWATEJ LEPIDOCEPHALICHTHYS GUTEA ORAZ Z WÓD \\ RZEKI TERAI LOTCHKA, ZACHODNI BENGAL, INDIE.
}

\section{STRESZCZENIE}

Przeprowadzono badania nad izolacją, identyfikacją i opornością na antybiotyki bakterii z rodzajów Aeromonas spp. i Salmonella spp. pobieranych ze skrzeli, skóry i jelit słodkowodnej ryby pisokorzowatej Lepidocephalichthys guntea (Hamilton Buchanan), a także z prób wody pochodzącej z czterech stanowisk badawczych na rzece Lotchka, w prowincji Darjeeling, Zachodni Bengal, Indie. Identyfikację bakterii prowadzono metodami biochemicznymi, weryfikując je przez analizę specyficznego markara genetycznego 16S rDNA. Wrażliwość na antybiotyki przeprowadzono metodą krążkowodyfuzyjną. W sumie wyizolowano 49 Aeromonas spp. i 24 Salmonella spp. Maksymalna oporność badanych bakterii wykazywana była w stosunku do penicyliny-G (benzylopenicylina), ampicyliny i cefalotyny. Oporność na cyprofloksacynę i tetracyklinę była prawie zerowa. Wykazano, że woda rzeczna jak i zasiedlające ją ryby są skażone patogennymi, opornymi na liczne antybiotyki bakteriami. Badania te dostarczają wartościowych danych dla ośrodków decyzyjnych ukazując potrzebę redukcji skażenia mikrobiologicznego ryb i nielimitowanego używania antybiotyków.

\section{REFERENCES}

Al-Jebouri M.M. 1985: A note on antibiotic resistance in the bacterial flora of raw sewage and sewage-polluted river Tigris in Mosul, Iraq. J. Appl. Bacteriol. 58: 401-405.

Al-Harbi A.H. 2003: Faecal coliforms in pond water, sediments and hybrid tilapia (Oreochromis niloticus X Oreochromis aureus) in Saudi Arabia. Aquat Res. 34: $517-524$. 
Alpay-Karaoglu S., Ozgumus O.B., Sevim E., Kolayli F., Sevim A., Yesilgil P. 2007: Investigation of antibiotic resistance profile and TEM-type $\beta$-lactamase gene carriage of ampicillin- resistant Escherichia coli strains isolated from drinking water. Annal. Microbiol. 57: 13

Amit-Romach E., Sklan D., Uni Z. 2004: Microflora Ecology of the chicken intestine Using 16S Ribosomal DNA Primers. Poultry Science. 83: 1093-1098.

ANON 2001: Handbook of Fishery Statistics 2000: Ministry of Agriculture, Government of India.

Apun K., Yusof A.M., Jugang K. 1999: Distribution of bacteria in tropical freshwater fish and ponds. Int. J. Environ. Health Res. 9: 285-292.

Barrow G.I., Feltham R.K.A. 1993: Manual for the Identification of Medical Bacteria, 3rd edition. Cambridge University Press, Great Britain.

Bauer A.W., Kirby W.M.M., Sherries J.C. 1966: Antibiotic susceptibility testing by a standard single disc method. Am. J. Clin. Pathol. 45: 493.

BLACK R.E. 1993: Persistent diarrhoea in children in developing countries. Pediatr. Infect. Dis. J. 12: 751-761.

Bone Q., Marshall N.B., Blaxter J.H.S. 1996: Biology of Fishes, $2^{\text {nd }}$ edition. Chapman \& Hall, London.

Cahill M.M. 1990: Bacterial flora of fishes: a review. Microbiol. Ecol. 19: 21-41.

Cheesbrough M. 2000: District Laboratory Practice in Tropical countries. Cambridge University Press.

Chelossi E., Vezzulli. L., Milano A., Branzoni M. Fabiano M., Riccardi G., Banat I.M. 2003: Antibiotic resistance of benthic bacteria in fish-farm and control sediments of the Western Mediterranean. Aquaculture. 219: 83-97.

Costanzo S.D., Murby J., Bates J. 2005: Ecosystem response to antibiotic entering the aquatic environment. Mar. Poll. Bull. 51: 218-223.

Daughton C.G., Ternes T.A. 1999: Pharmaceuticals and personal care products in the environment: agents of subtle change? Environmental Health Perspectives. 107: $907-938$.

DAVIES J. 1994: Inactivation of antibiotics and the dissemination of resistance genes. Science. 264: 375-82.

El-Sheikh S.M., El-Assouli S.M. 2001: Prevalence of viral, bacterial and parasitic enteropathogens among young children with acute diarrhoea in Jeddah, Saudi Arabia. J. Health Pop. Nutr. 19 (1) 25-30.

Fernandez A., Fernandez de., Aranguiz A. A., Umaran A., Cisterna R. 1990: Comparison of antibiotic resistance and plasmid bands between two identical sets of raw sewage enterobacterial strains. Acta Hydrochim. Hydrobiol. 18: 345350.

Gomes-Lus R. 1998: Evolution of bacterial resistance to antibiotics during the last three decades. Internat. J. Microbiol. 1:281-288.

Gonzalez C.J., Díaz López T.M.L., Prieto M., Otero A. 1999: Bacterial microflora of wild brown trout (Salmo trutta), wild pike (Esox lucius), and aquacultured rainbow trout (Oncorhynchus mykiss). J. Food Protect. 62:1270-1277.

Hatha M., Vivekanandhan A.A., Joice G., Christol H. 2005: Antibiotic resistance pattern of motile aeromonads from farm raised fresh water fish. Int J Food Microbiol. 98: 131-134.

Heinitz M. L., Ruble R.D., Wagner D.E., Tatini, S.R. 2000: Incidence of Salmonella in fish and seafood. Int. J. Food Microbiol. 63: 579-592. 
Hirsch R., Ternes T., Haberer K., Kratz K.L. 1999: Occurrence of antibiotics in the aquatic environment. Sci. Tot. Environ. 225: 109-118.

Holt J.G., Krieg N.R., Sneath P.H.A., Williams S.T. 1994: Bergey’s Manual of Determinative Bacteriology, 9th edition. Williams and Wilkins, Baltimore.

JAnda J.M., Аввотт S.L. 1998: Evolving concepts regarding the genus Aeromonas: An expanding panorama of species, disease presentations and unanswered questions. Clin. Infect. Dis. 27: 332-344.

JHA P., Roy R.P., Barat S. 2010: Application of sensory and microbial analysis to assess quality of fish in Siliguri city of West Bengal, India. J Environ Biol. $31: 587-594$.

Jones J.G., Gardener S., Simon B.M., Pickup R.W. 1986: Antibiotic resistant bacteria in Windermere and two remote upland tarns in the English Lake District. J. Appl. Bacteriol. 60:443-453.

Lee C., Cho J.C., Lee S.H., Lee D.G., Kim S.J. 2002: Distribution of Aeromonas spp. as identified by $16 \mathrm{~S}$ rDNA restriction fragment length polymorphism analysis in a trout farm. J Appl Microbiol. 93: 976.

LeE D.H., Zo Y.G., KIM S.J. 1996: Nonradioactive method to study genetic profiles of natural bacterial communities by PCR single-b strand-conformation polymorphism. Applied and Environmental Microbiology. 62: 3112-3120.

MacMillan J.R. 2001: Aquaculture and antibiotic resistance: a negligible public health risk?. World Aquacult. 32: 49-50.

Massa S., Alitera C., D'angela A. 2001: The occurrence of Aeromonas spp. in natural mineral water and well water. Int. J. Food Microbiol. 63: 169-173.

Mato R. 2002: Groundwater Pollution in Urban Dar as Salaam, Tanzania. Assessing vulnerability and protection priorities. PhD Thesis, Eindhoven Technische Universitiet.

McKeon D.M., Calabrese J.P., Bissonnette G.K. 1995: Antibiotic resistant gramnegative bacteria in rural groundwater supplies. Water Res. 29: 1902-1908.

Mondal D., Barat S., Mukhopadhyay M.K. 2007: Toxicity of neem pesticide on a fresh water loach, Lepidocephalichthys guntea (Hamilton Buchanan) of Darjeeling district in West Bengal. J Environ Biol. 28(1): 119-122.

Nath G., Shukla B., Reddy D., Sanyal S. 1993: A community study on the aetiology of childhood diarrhoea with special reference to Campylobacter jejuni in a semi-urban slum of Varanasi, India. J. Diarrhoeal Dis. Res. 11: 165-168.

Oвi C. L., Coker A.O., Epoke J., Ndip R.N. 1997: Enteric bacterial pathogens in stools of residents of urban and rural regions in Nigeria: A comparison of patients with diarrhoea and controls without diarrhoea. J. Diarrhoeal Dis. Res. 15 (4): 241-247.

Oкрокwasili G.C., Alapiki A.M. 1990: Bacterial flora associated with a Nigerian freshwater fish culture J. Aquac Trop. 5: 87-90.

Panigrahi A.K., Dutta S., Ghosh I. 2009: Selective study on the availability of indigenous fish species having ornamental value in some districts of West Bengal. Sus Aqua. 14(4): 13-15.

Pathak S.P., BhattacherJee J.W., Ray P.K. 1993: Seasonal variation in survival and antibiotic resistance among various bacterial populations in a tropical river. J. Gen. Appl. Microbiol. 39: 47-56.

Pathak S.P., Gopal K. 2005: Occurenace of antibiotic and metal resistance in bacteria from organs of river fish. Environmental Research. 98: 100-103. 
Prado V., O'ryan M.L. 1994: Acute gastroenteritis in Latin America. Infect. Dis. Clin. North Am. 8: 77-106.

Rang H.P., Dale M.M., Ritter J.M. 1999: Pharmacology. Churchill Livingstone, Edinburgh.

ROY R.P., BARAT S. 2011: Influence of water quality on the bacterial contamination of resident loach, Lepidocephalichthys guntea (Hamilton Buchanan) and on a Terai River Lotchka of Darjeeling District, West Bengal, India. Arch. Environ. Sci. 5: 116-123.

SAHA D., PAL J. 2002: In vitro antibiotic susceptibility of bacteria isolated from EUSaffected fishes in India. Letters in Applied Microbiology. 34: 311-316.

Sakata T., Uno K., Kakimoto D. 1984: Dominant bacteria of the aerobic microflora in tilapia intestine. Bull. Jpn. Soc. Sci. Fish. 50: 489-493.

Sakthivel M. 2003: The challenges to introduce "fish for all" in India. In: Fish for All: National Launch, Kolkata (December 18-19, 2003). MSSRF/PR/03/52. MS Swaminathan Research Foundation, Chennai. pp. 83-89.

Schmidt A.S., Bruun M.S., Dalsgard I., Pedersen K., Larsen J.L. 2000: Occurrence of antimicrobial in fish pathogens and environmental bacteria associated with Danish rainbow trout farms. Appl. Environ. Microbiol. 66: 4908-4915.

Schwartz T., Kohenen W., Jansen B., Obst U. 2003: Detection of antibiotic resistant bacteria and their resistance genes in wastewater, surface water, and drinking water biofilms. FEMS Microbiol. Ecol. 43: 325-335.

Smith A.J., Balaam J.L., Ward A. 2007: The development of a rapid screening technique to measure antibiotic activity in effluents and surface water samples. Mar Pollut Bull. 54:1940-1946.

Sugita H., Ishida Y., Deguchi Y., Kadota H. 1982: Aerobic microflora attached to the wall surface in the gastrointestine of Tilapia nilotica. Bull. Coll. Agric., Vet. Med. Nihon Univ. 39: 302-306.

Talwar P.K., Jhingran, A.G. 1991: Inland Fishes of India and Adjacent Countries, Vol. I, Oxford \& IBH Publishing Co. Pvt. Ltd. New Delhi, Calcutta.

Tenover F.C., McGowan J.E. 1996: Reasons for the emergence of antibiotic resistance. Am J Med Sci. 311: 9-16.

Toroglu S., Dinçer S., Korkmaz H. 2005: Antibiotic resistance in gram negative bacteria isolated from Aksu river in (Kahramanmaras) Turkey. Ann. Microbiol. 55: 229-233.

Walsh T.R., Payne D.J., MacGowan A.P., Bennett P.M. 1995: A clinical isolate of Aeromonas sobria with three chromosomally mediated inducible betalactamases: a cephalosporine, a penicillinase and a third enzyme, displaying carbapenemase activity. J. Antimicrob. Chemother. 35:271-279.

Witte W. 1998: Medical consequences of antibiotic use in agriculture. Science. 279: 996-997.

World Fish Centre: Fish 2002: An Issue for Everyone. A Concept Paper for "Fish for All”. World Fish Centre, Penang. 